\title{
The Systematic Implementation of an Innovative Postgraduate Online Learning Model in the Middle East
}

\author{
Nessrin Shaya \\ American University in the Emirates, Dubai, United Arab Emirates \\ https:// orcid.org/0000-0003-4201-3945 \\ Laila Mohebi \\ Zayed University, Dubai, United Arab Emirates \\ https://orcid.org/0000-0003-2640-4532
}

\begin{abstract}
This paper aims at examining the factors contributing to effective implementation of online learning in the Middle East higher education sector, through investigating the success and learning effectiveness of an innovative online learning model offered jointly by three prestigious universities in two different Arab countries. A mixed-method research approach was employed to triangulate data collected from key stakeholders engaged with the programme, namely senior managers and enrolled students, to derive findings that would inform managers, trainers and educators, from a systemic implementation, faculty-development and course-design perspective. Qualitative data gathered from face-to-face, semistructured interviews with a number of senior managers took place delineated on the necessary enabling conditions to create, design and offer a quality online programme. Quantitative data collected from a student satisfaction survey examined factors contributing to perceived learning and student satisfaction in an online learning context. Following thematic analysis, five major factors were identified as critical for effective online learning implementation, namely: Rationale and Motivating Factors, Technology Infrastructure, E-Learning Pedagogy and Support Infrastructure, Course Design and Delivery and Lessons Learned. Results showed that Course Structure/Organisation, Learner Interaction, Student Engagement and Instructor Presence appeared to be the major factors contributing to high satisfaction and perceived learning. This paper argues that the shift towards blended and online modes of learning is inevitable, advocating the fundamental conception that online education is instrumental in expanding access to tertiary education. If properly designed and implemented, online education has the potential to alleviate academic rigor through improved faculty productivity at reduced tuition costs. Implications for further research and practical recommendations are also discussed.
\end{abstract}

Keywords: course delivery; course design; higher education; online education; perceived learning; student satisfaction; success factors 


\section{Introduction}

While the education culture across the Middle East values campus-based learning, the shift towards blended and online modes of learning is inevitable. Despite reported benefits in holding a repertoire of learning opportunities, the absence of legal frameworks supporting recognition of online degrees is the biggest hurdle towards embracing online education (The Open University, 2021). An examination of the dominant features of education and academic institutions of the third millennium shows that chief characteristics are "flexibility, inclusiveness, collaboration, authenticity, relevance and extended institutional boundaries" (Yuksel, 2010, p. 1). Responsibilities of learners and lecturers have transformed significantly as educational goals have expanded to include selfdirected learning, digital literacy, continuous global dialogue, attainment of metacognitive skills and processes that comprise holistic curricula, critical thinkers and problem-solvers. Accordingly, higher education must undergo necessary changes to adapt the traditional educational structures to the uprising knowledge age, represented through the integration of information technology denoted by the 'digital age'. This research advocates the fundamental conception that online education is instrumental in expanding access to tertiary education, yet, has the potential to alleviate academic rigor and standards through improving faculty productivity at reduced tuition costs (Carey \& Trick, 2013; Meyer, 2012). Therefore, it focuses on an innovative online programme that is the first of its kind launched in the nation, offered in a joint collaboration between three American universities in Lebanon and Egypt, breaking down a number of cultural, social and political barriers. In a country where online education is yet to be approved and recognised, this programme is revolutionary for the Lebanese community (Malaeb, 2020), capturing the attention of significant stakeholders and official regulators, monitoring results and effectiveness, poising for further growth and supporting the uprising of the nation. Therefore, the current research understudy will focus on the Lebanese context.

What is more, is the fact that only a small number of studies have been carried out in the Middle East to investigate the future prospects and barriers towards implementing online education (Baytiyeh, 2017; El Turk \& Cherney, 2016). However, with the constant growth of the Web influences and changes in how online courses are designed and implemented, continuation of studies of learners' perspectives of online learning environments are needed to build effective Webbased instruction that can optimise the learning experience within this everchanging landscape. This study seeks to add to the theoretical body of knowledge and literature, the experiences of online education in Lebanon, the prospects and challenges.

Over the past years, distance education has remarkably altered the landscape of modern education, advancing significant changes in the offered learning opportunities. A myriad of literature ascertains that online education can emerge as a powerful socio-economic force in combating education inequalities and poverty and driving economic development (Burns, 2017; Li \& Lalani, 2020). Despite reported benefits, institutional efforts to experiment with online modalities of teaching and learning were frequently assessed by the government 
(El Ghali \& Nauffal, 2020). Accordingly, this paper reports on an innovative online post-graduate engineering diploma programme that is considered to be revolutionary for Lebanon, monitored by many significant stakeholders (Baytiyeh, 2017) such as the Ministry of Education and Higher Education in Lebanon. This is done to better understand the readiness and commitment of students and the impact of the educational experience in terms of learning effectiveness, academic integrity and student satisfaction. The success of the programme will contextualise the country as a possible market for online education and poises for further growth and possible approval of online education. Accordingly, this study aims to present the first approved postgraduate online diploma as a foundational stage for potential growth of the industry in Lebanon. This mixed-method case study approach aims to answer the following research questions:

- What are the main factors contributing to effective implementation of online learning in the higher education sector in Lebanon?

- How satisfied were students with their fully online courses?

- What factors contributed to students' satisfaction with online learning?

In an attempt to get on with global progress and support the current efforts, the findings will be framed and presented as a model on the most appropriate mode of implementation of online education in Lebanon.

\section{Significance of Research}

At times where the West has adopted and implemented online learning since long time and is continuously experimenting with and trying out innovative models as learning solutions, till now Lebanon does not approve online education and applications for equivalency of online degrees are faced with refusal, despite how prominent and reputable the graduating universities are (Baytiyeh, 2017; El Turk \& Cherney, 2016). A number of hindering factors towards implementation of online education have been reported, among which is the lack of trust in underlying teaching effectiveness and academic rigor, the absence of the Lebanese Quality Assurance Agency to audit quality and abundance of higher educational institutions, relative to a small country in geographical area like Lebanon (El Amine, 2017). Therefore, it is not surprising that investments in e-learning in the Middle East fall second to last behind Africa, equivalent to $\$ 683$ million by 2016, whereas North America ranks first with $\$ 23$ billion worth of investments in the same fiscal year (El Amine, 2017). The Ministry of Education and Higher Education has put forward some efforts in embracing online education, such as creating a taskforce of different expertise to draft a national strategy and create a framework of action to recognise and accredit distance learning, yet the most serious efforts remain from two leading American universities in Beirut and the Arab Open University, a branch of the online learning network (El Turk \& Cherney, 2016).

Shaya (2018) argues that primitive systems continue to override the work of higher education legislative academic decision-makers in Lebanon which is not on par with advancements happening in the education system worldwide, hence, denying institutions the chance to maintain a competitive advantage in a fastchanging market and provide better quality and access to education. Those 
universities which do not embrace online education will be left behind in the race for globalisation and technological development. It is anticipated that the study of the effectiveness of current online practices will bring about the quality of online education and bring confidence among the regulatory authorities on the need to accredit and approve this revolutionary mode of education on par with the West. On the other hand, the perception offered by faculty members teaching at leading institutions in Lebanon has the potential to expand awareness among students and parents and lead to a change in the attitudes in perceiving the need for online learning. Finally, and most importantly, the results of the study present as an implementation model for private institutions on the best ways to deliver quality online instruction in the most cost-effective ways that can meet learners, market and business needs.

\section{Theoretical Framework and Literature Review}

The current research understudy is part of a larger stakeholder analysis study that reports on the country's readiness to accredit and implement online modes of teaching and learning. The stakeholders are mainly higher education students, faculty, executive leaders of private universities and the federal legislative authorities. It is governed by the theoretical conception of Aparicio et al. (2016) that perceives any successful e-learning system as a function of three main pillars: e-learning stakeholders, e-learning technologies and e-learning activities. Hence, this study presents the experience of the first postgraduate online programme as a foundational ground to build upon, making use of the lessons learned, bringing confidence in the capacity of private higher education institutions to carry out such innovative models and unravel the prospects and challenges. These elements guided the investigation seeking perceptions pertaining to faculty, students and developers as main stakeholders, the e-learning team in particular, to deeply understand the status of online learning technologies incorporated, the instructional designers and faculty to report on pedagogy and online activities and students to unravel the quality of learning and instruction versus expectations.

The study is the first official postgraduate online programme to be offered in Lebanon. Eighteen credits are required towards the completion of the diploma, with quality of delivery and content sought to be equivalent to face-to-face instruction, as indicated by the Ministry of Education and Higher Education in Lebanon (Baytiyeh, 2017). Many internal policies and regulations govern the diploma such as admission and registration procedures, duration of the study, curriculum and syllabus. Hence, it is deemed necessary to document the systematic implementation of the programme and assess student satisfaction.

\section{Related Work}

A number of international studies (Archambault \& Crippen, 2014; Albrahim, 2020; Basilaia \& Kvavadze, 2020; Fauzi \& Khusuma, 2020) have documented academic rigor following online delivery. For instance, Shutimarrungson et al. (2014) studied the implementation of the constructivist model in an online learning course and results indicated that participants achieved high score achievement and high critical thinking skills on post-tests. Studying the nature of the learning 
experience it was revealed that the activities challenged the learners to develop higher-order thinking skills and encouraged them to connect with former experience and respond to the diversity of the learning needs, which lead to authentic learning.

This study, among many other studies in literature, supports the conception that pedagogy shapes the efficiency of online programmes, and if properly implemented can lead to significant achievement gains and better learning outcomes. Scrutinising the most appealing pedagogical features in online education, the literature reveals the following factors. First, teachers serve primarily as guiders and facilitators of learning, not instructors. Learning is learner-centred (Brookfield, 1995; Chen, 1997; Huang, 2002; Schell \& Janicki, 2012; Spitzer, 1998; Wagner \& McCombs, 1995). Second, learning takes the form of realworld scenarios emphasising authentic learning (Carwile, 2007; Doolittle, 1999; Jonassen et al., 1994; Koohang et al., 2009). Third, the social presence of students by way of incorporating negotiations, discussions and debates should also be considered (Chickering \& Gamson, 1991; Chickering \& Ehrmann, 1996). Fourth, content should be meaningful and students should build on their pre-existing knowledge. Fifth, students should be prompted to hold themselves accountable for their learning, hence, to become self-mediated and self-aware, given that a safe environment for questioning and learning is provided. Finally, teachers should provide and encourage multiple perspectives and representations of content (Chickering \& Gamson, 1991; Chickering \& Ehrmann, 1996). On the other hand, upon reviewing the literature, the trends for 2017 to 2018 (Jasmini, 2017) appear to be:

- Contextualised learning, represented through modernisation of current elearning system designs and approaches.

- Two-way conversation in e-learning, where learners' needs will inform content rather than available resources or classical approaches. For instance, an 'e-learning authoring' tool could be used to fetch needs and elicit responses through sending out polls and questionnaires that will then in turn help to shape strategy and content.

- Better use of data, where option such as 'Elucidat' can allow viewing analytics that would help in realising pitfalls and draw plans for personalising and improving learning content.

- Extensive use of videos in terms of social learning and video learning in online courses. Options like 'Elucidat' and 'Periscope' provide a variety of features to build interactive videos and for better use in designing content.

- Microlearning will be used to personalise e-learning content.

- Social e-learning or 'informal learning' provided through e-learning experiences.

- Mobile learning will continue to rise and learning content will be more accessible through mobile devices.

- Performance support vs learning experience.

\subsection{The Growing Market of E-Learning in the Middle East}

The $21^{\text {st }}$ century in the Middle East has witnessed growing interest in e-learning through considerable investments in innovation leading to better e-learning 
solutions, while the latter market revenue has risen to $\$ 560.7$ million by 2016 (Edarabia, 2016). The e-learning and online education market was valued at $\$ 558.1$ million in 2016 and is expected to reach $\$ 237.1$ million by 2023. The Kingdom of Saudi Arabia holds the largest shares in the Middle East and North African (MENA) market, with expectations of earnings reaching \$237 million by 2023 as well. As a result, the Middle East Online Education and E-Learning Market Size, Demand, Opportunity and Growth Outlook 2023 (Research and Markets, 2017) report has been issued from Dublin to reflect and accompany the spanned growth. The report presents historical market data for the previous year, and at the same time reflects revenue estimates and forecasts till 2023. The scope includes market trends, strategical management and development issues and so on. Internationally, recruitment for online education has achieved numerous gains and progress, with a reported enrollment of 308,000 at the University of Phoenix, leader of online learning in higher education, 78,000 at Kaplan University, and about 62 universities offering at least one course on Massive Open Online Courses (MOOCS) platforms, including Stanford (Bonvillan \& Singer, 2013).

\subsection{The Programme Under Study}

In October 2012, the main hosting university in Lebanon received a grant from the European Union to offer an online joint/dual professional diploma and a degree in green technologies (Uni-Med, 2021). The project originally aimed at widening access to Information and Communication Technology ICT through incorporating the use of new technologies in teaching and learning.

Three main aims resulted, with the first the development of 'Visio-conferencing', then online courses and an online joint postgraduate diploma.. Three leading American universities in Lebanon and Cairo partnered in offering an international diploma. The funding process was completed by August 2016 and the diploma has currently three main specialisations, namely renewable energies, green buildings and water resources. The project aimed at developing programme structure and curriculum for a postgraduate degree in green technologies, creating a platform for the development of blended learning and a training faculty.

\section{Methodology}

Charmaz (2006) defines grounded theory as "an inductive, comparative methodology that provides systematic guidelines for gathering, synthesising, analysing and conceptualising qualitative data for the purpose of theory construction" (p.2). Hence, an inductive grounded theory methodology has been utilised in the current understudy aiming at developing theoretical models with high levels of rigor. Therefore, the research design covered two main stages:

(i) Qualitatively identifying the main themes, through thematic analysis, that contribute to learning effectiveness from programme design perspective, to delineate on the necessary enabling conditions to create, design and offer a quality online programme. Particularly, the opinions offered by the managing director of the programme, teaching faculty members, the e-learning team supporting the programme comprising the general manager, instructional designers and multimedia designers, were instrumental. 
(ii) Quantitatively assessing the factors contributing to student satisfaction and perceived learning.

Data was collected primarily through document analysis, interviews and surveys. Fifteen audio-recorded semi-structured interviews were carried out with professionals holding senior positions in the design, development and implementation stage of the programme. The subjects' qualifications ranged between Masters' and PhD holders who have worked closely on developing the programme. Four of the subjects were senior college Deans and a total of twelve were faculty with ranks ranging between assistant and full professors. Ten were females and five were males. In addition, among the interviewees were senior instructional designers and IT specialists. Interviews were first piloted, where interview question guides and procedures were verified and cross-checked by two academicians who are experts in the field, at the rank of full professor and associate professor, to ensure question rigor through avoiding any potential ambiguity, bias or leading questions. Each interview lasted between 60 and 90 minutes. There were 10 to 17 questions based on each interviewee's position and the interview questions were categorised under main themes in an attempt to facilitate data analysis. A qualitative approach was adopted to identify emerging factors under the assigned main themes and finally data was scrutinised and interpreted iteratively leading to formation of codes and themes. Subjects' responses were organised in a table form design comprising each subject's code name, main themes, codes revealing subjects' individual perceptions and corresponding quotes. Then, thematic analysis was utilised to look for patterns and themes across datasets. Findings took the form of locating emerging themes and sub-themes, where emerging codes were considered as potential themes in a manner where various codes merge towards forming dominating themes.

On the other hand, for the purpose of data on student satisfaction, this research study employed the Student Learning and Satisfaction in Online Learning Environments (SLS-OLE) survey that was developed by Gray and DiLoreto (2016), which has been proven for validity and reliability. A convenience sampling approach was followed. A five point Likert scale for the questionnaire was used, prompting students to assign their level of satisfaction with the programme. The questionnaire was circulated electronically to the students enrolled in the online diploma programme. A total of sixty responses were collected, representing the majority of enrolled population with a $60 \%$ response rate, given that it is a new and unique programme. Data was analysed using SPSS to generate descriptive statistical results while being continuously cross checked to verify validity of responses. The questionnaire was first factor analysed, with minimal loading cutoff score to be \pm 0.5 (Suliman 2001). The factors were successfully loaded scoring 0.59 and above on the varimax rotation. Knowing that the determinant of the R-matrix should be greater than 0.00001 (Field 2005), the determinant in this study was found to be .002, that is larger than the necessary value. The value of $\mathrm{KMO}$ is .733 meaning that factor analysis results in reliable factors (2005), and the Bartlett test appears to be significant with value .03, and accordingly factor analysis yielded reliable findings. Given the scarcity of available information as the diploma is the first of its kind in the country that is online and approved, and, while the whole nation has their eyes open, namely regulatory authorities and 
different university councils, to understand the pre-requisites for successful implementation and lessons learned, every single response will be of great value and worth. Many studies acknowledge the importance of the online diploma programme understudy as a European funded project that will revolutionise the education system in Lebanon, hence, it is deemed important.

\section{Demography of Respondents in Quantitative Data}

A total of 60 students responded with meaningful answers on the survey. Around $70 \%$ of them are of the age group 24 to 34 years old, one is below 24 and the remainder are above 35 . The majority of the respondents were married and were males, around $82 \%$ and $75 \%$ of the total respectively, and the remaining were unmarried. As expected, the largest group lead full time jobs (88\%), whereas the rest were equally distributed as either working a part-time job or were unemployed by the time data was collected. All respondents reported CGPA between 2.00 and 4.00, and three quarters of the group scored above 3.00 and the remainder below this. Finally, $82 \%$ were of Lebanese nationality, while $18 \%$ were non-Lebanese.

\section{Qualitative Findings on Implementation of Programme}

Five main factors emerged as important to the implementation of the online learning programme in Lebanon, namely:

- Rationale and Motivating Factors

- Technology Infrastructure

- E-Learning Pedagogy and Support Infrastructure

- Course Design and Delivery

- Lessons Learned

\section{A- Rationale and Motivating Factors}

Given the European project funding, the initial aim of the project was to develop a number of online courses that would lead to a certificate. However, the desire was high and findings from feasibility studies brought about a niche in the market requiring postgraduate diploma studies in green technologies, and accordingly the decision was taken.

RR: There was no initial intention to develop a diploma, rather online courses in green energy, but aspirations were high and market research showed that there was a niche to develop this into a diploma.

The leading American university hosting the programme has been offering blended learning delivery for 10 years, since 2008, and has the capacity through its e-learning team comprised of 12 experts to develop quality online modules. Three universities embraced the project, namely three American universities, two in Lebanon and another in Cairo. The international partners helped the three main universities in turning the fragmented parts into one full programme, which is offered completely online, to be the first in Lebanon and some of its neighbouring countries.

$R R$ : The main leading university has an advantage because they have a small group of specialised people instructional designers to help in assessment and testing in online education, do frequent testing rather than one midterm. They helped the faculty. 
The diploma programme was launched even before the funding was complete. Presently, more than 27 online courses have been designed and delivered, $90 \%$ of students are new to the world of online education, students allocate at least 5 to 7 hours per week to study per course, and they are residents from different parts of the world. Accordingly, the regulatory authority has approved the programme and is is aware of the success of the online diploma programme

RR: Our degree is almost equivalent to Masters' courses, and the ministry is very attentive to it because we are the first.

Offering a post-graduate online programme extends far beyond the online diploma programme for the main leading American university, where shifting to online modes of delivery is part of the university's strategic planning. The university aims towards increasing the international student body and to increase student enrollment by half. Given available space and resources, going virtual is therefore one element of the Master Plan. Therefore, solid efforts are placed on intensifying e-learning resources, such as reliable cloud hosting, an e-learning platform and learning management system.

WW: Our strategical plan is to increase enrollment by $50 \%$ without increasing the space, without increasing facility, and the only way is to go virtual. This one of the items in the Master Plan. Therefore, we are placing extensive efforts in our e-learning resources, on reliable cloud hosting stable, even though I think we have accomplished a success story since 2005.

\section{B- Technology Infrastructure}

From an operational perspective, the programme functions along with three main components: admission, registration and learning management system. Moodle and Blackboard are the main learning management systems utilised. To overcome the problem of slow and low quality of Internet service, the leading university had a British partner offering an external hosting cloud in addition to the Moodle partner.

WW: Our institution has a team dedicated to implementing online courses, we contacted different companies, looked for Moodle partners, not only hosting cloud, so we took a SAS, software as a service, we contacted different companies and we selected a partner in UK.

All the implementation of Moodle happens locally at the leading university, where every semester the online diploma programme has 10 to 15 courses running through Moodle, that are reliable and efficient, with no incidents registered such as hacking and server problems. The e-learning team acknowledges the importance of training for students, where upon enrollment, new students receive intensive training either through Skype or Adobe Connect. The support team is available almost all the time and issues are usually resolved within two hours.

\section{C- E-Learning Pedagogy and Support Infrastructure}

The concept of integrating technologies into teaching and learning is not new at the main leading American university, rather an extension of efforts that stretched for several years back. Training sometimes took the shape of a full programme that would last many weeks, on best practices, reading content, then finally 
authoring their own courses that would meet certain objectives. At least twelve different faculty members are called for training every semester.

Regarding the online diploma pedagogy, the fundamentals of online pedagogy are well governed. A number of specialised instructional designers, who are experts in the field of online education, are on the board. The designers' duties, in collaboration with multimedia designers and e-learning system managers, are to:

- Train faculty members in using e-learning technologies and associated pedagogies prior to any activity.

- Through one-on-one and collective group meetings, to closely assist faculty members in desigining their courses, then to transform them into online learning modes.Test the courses and verify their quality prior to publishing and delivery. In that case, many courses were turned down because they were not cleared by the instructional designers.

- Follow up on faculty members during the semester.

Custom-designed training sessions, in addition to one-on-one support, is offered to every new faculty member joining the diploma for three to four months, whereby training and designing of the course takes place. In essence, almost three quarters of the course should be ready prior to offering it up for study. The instructional design team helps in finding the best methodologies for teaching the course, relying on the most suitable learning activities, graphics and assessment, and accordingly the syllabus might need to be modified and other types of interactive engagement assignments included.

HH: Every time new faculty joining, individual work of 1-1 for about 3 $4 /$ months to train and design a course takes place.

MM: They come with topic learning outcomes and syllabus, we assist them in methodologies of teaching, design activities and learning modules, we help to choose learning activities, assessment, etc. They write the preliminary syllabus and textbook then we work on redesigning syllabus to develop appropriate assessment, as they are used to classical quizzes and exams, whereas we train them on different kinds of assessment and interactive engagement documents.

With time faculty members become proficient in online learning systems, where members reported better student evaluation reports and general internal satisfaction after teaching online courses for some time.

\section{D- Course Design and Delivery}

Reflections on course design and delivery were brought about through the perceptions of faculty members teaching online courses in the online diploma programme. The first faculty member is an associate professor in Engineering, with teaching experience of more than 10 years. He has been engaged in a blended learning approach at the leading university since 2013 and received a total training of 10 to 12 hours after joining the online diploma programme. The workshops were just a start, rather, it is the on-the-job training and exposure that reinforce the necessary skills to deliver high quality teaching. He teaches two courses, each two credit hours, and each requires around nine to 10 sets of lectures each lasting for about 40 minutes on average. 
II: For each of these courses there is like 9 or 10 set of lectures, about 40 mins each.

II: It is the OJT, on job training, when you start actually experimenting with online, there is a lot of learning that takes place.

Content development happens locally, where the faculty member gets the syllabus with learning outcomes along with assigned topics. Then instructional designers will undergo some modifications on instructional strategies, replace paper books with e-books and alter assessment to be quiz-based into a set of different assessment techniques such as position paper, presentation, critique and others.

With the help of instructional designers, the faculty prepares the material using a PowerPoint Presentation with very interactive slides, supplemented with videos, graphics, etc. Then with the help of multimedia specialists, voice over is recorded, then through a e-learning technologies manager, the slides would be turned into online material using specialised software. A simple link would allow students to download and access the slides.

Regarding assessment, the faculty confirms that conducting online quizzes remains a problem in the diploma programme as it is difficult to verify the identity of the user taking the quiz and to check that cheating is not happening. However, what helps is the nature of the candidates who are pursuing the diploma for career advancement and self-satisfaction, hence any kind of plagiarism wouldn't help them. In all cases, minor weight is assigned to online quizzes $(20 \%)$ and the main weight is on assignments. The faculty gives about eight assignments every semester, in the form of mini-projects. They are asked to undertake some reading of a material or research/paper and then a report and exercises are then shaped so that students will have to comment on each other's work. Eventually, they are learning and critiquing and students are interacting where questions go back and forth between them, while the faculty members monitor the interaction and interfere only when required. An assignment that initiates dynamic discussion and keeps the students engaged would help in meeting the learning outcomes, rather than the grade itself.

Issues like monitoring attendance are not hard, as the system allows the faculty to keep track of the activity of the student, slides visited, how much time is spent and when it is necessary to initiate and contact the student regarding attendance.

\section{E- Challenges Faced and Lessons Learned}

Findings were obtained from different interviewees on the lessons learned over the three years since the diploma was offered at the university, as follows:

(i) Offering online degrees (or diplomas) by any reputable university takes long extensive effort, and as one senior executive mentioned "it might look like something small, but the effort is like introducing a $\mathrm{PhD}$ programme. The difficulty lies in meeting local, regional and international registration and accreditation of enrolling universities, which is almost equivalent to reaccreditation". Hence, from an administrative perspective, serious commitment is required.

(ii) GG: We worked on the administration to make sure the team in our university is doing its part in admission and registration, it might look something small, but the effort is 
like introducing PhD program, getting IDs, online tuition fees, everything online, to get all this done banner oracle financial system huge amount of money. Despite its operational difficulties, the online diploma is very profitable. It has achieved profit from the first day of launching, indicating a good market for the online diploma, although it is typically new.

(iii) GG: This is a diploma that made money from the very first semester, it actually made profit, making good money for all the 3 partners. Tuition fees is basic, very affordable, the way we designed it, the way we shared our resources, the university charges overhead and yet we are still making money. It is a very good opportunity. The presence of strong technological infrastructure is essential to ensure smooth automated progression between admission, registration and course navigation.

WW: All transitions between the three units Admission, Registration and Moodle is automated, and the units are from the leading university staff, who are experienced with more than 15 years of experience to increase chances of success, hence there should be a reliable hardware and software information technology.

(iv) The presence of specialised instructional designers in abundance is a must, where their main role is faculty development and to provide course design support. Training faculty members might seem brief, however, despite how knowledgeable they are, intensive training on teaching methodologies, formulation of their teaching identity and proper follow up on the students is hard to reach.

(v) Ample time of no less than three to four months should be given to prepare, test and pilot online courses before they are up and running. On average 20 to 30 slides will require 18 hours of extensive work to prepare, then three hours for audio -recording and two hours for post-production, i.e. publishing and posting. In addition, expectations should be set from the beginning for faculty members regarding due dates, deliverables and consequences if the commitment isn't fulfilled.

HH: Give the course enough ample time, minimum 3-4 months of preparation and testing, we pilot it user-testing, we do that with our media specialist. It takes long to develop interactive quality lectures.

(vi) Faculty members' social presence is very important and is underestimated, otherwise there is a risk of isolation of learners and low completion rates of courses. Online learning students need to continuously feel the presence of faculty members.

(vii) A reliable auditing system helps in controlling quality, where auditors are assigned to each online course and conduct satisfaction and progress surveys twice in a semester, in the middle of the semester and towards the end.

DD: Each course has assigned auditor. They conduct surveys middle of

the semester and by the end. Auditors make sure learning outcomes are met, and whether students are properly progressing.

(viii) Carrying out live sessions, whether for the purpose of synchronised learning or meeting the students in chat rooms and getting to know them better, appears to be effective in strengthening the faculty member-learner bond.

(ix) The personal effort required from a faculty member to teach an online course is by far greater compared to face-to-face instruction. Hence, monetary 
rewards as extrinsic factors will help, however, the faculty member should have intrinsic motivational factors to 'buy-in' to online courses and diminish resistance and reluctance.

KK: Yes, a lot, I am suffering in the diploma, though it is my second year of teaching online. Each semester I am changing the course. The courses I am teaching here are not introductory, rather advanced and not available. So, I have to always search for ways to make students very interested in the subject. It is nice, but very challenging. Switching online by itself is not hard but switching and making it interactive and interesting is not easy.

(x) Not all students are digital natives and 'tech-savvy'.

YY: My lessons learned that never assume that students are digital natives. Many times we take it for granted they feel at ease with technology, not all students do. We assume, if we give them any online platform they will naturally figure out what to do, that's not the case. Whether we like it or not there is a digital divide, especially in Lebanon.

\section{Results of Student Satisfaction Survey}

The questionnaire aims to assess student learning and satisfaction in the first and only accredited online programme in Lebanon, offered by partnering American universities in Lebanon and Cairo. Around 100 students were enrolled in total by the time the study was conducted.

The students' learning and satisfaction were measured based on six dimensions, namely: Course Structure/Organisation, Learner Interaction, Student Engagement, Instructor Presence, Student Satisfaction and Perceived Learning, and comprising 34 questions. The results are as follows:

\section{A- Course Structure/Organisation:}

Students' rating of the organisation of the course and structure yielded a mean of 4.15 and a standard deviation of .65. Strength appeared in clear statement of learning outcomes, ease of navigation and organised layout of course, where means were 4.25, 4.31 and 4.35 respectively. Moderate satisfaction was in the articulation of clear instructions on student participation and alignment of learning outcomes with activities.

Table 1: Course Structure/Organisation Results

\begin{tabular}{|l|l|c|c|}
\hline A- Course Structure/Organisation & Mean & SD \\
\hline 1 & $\begin{array}{l}\text { During your diploma courses, } \\
\text { student learning outcomes was } \\
\text { aligned to the learning activities. }\end{array}$ & 3.9375 & 0.57 \\
\hline 2 & $\begin{array}{l}\text { Course navigation was logical. } \\
\text { The layout of the course was } \\
\text { organised. }\end{array}$ & 4.3125 & 0.79 \\
\hline 4 & $\begin{array}{l}\text { Instructions about student } \\
\text { participation were clearly } \\
\text { presented. }\end{array}$ & 3.8125 & 0.63 \\
\hline 5 & $\begin{array}{l}\text { The purpose of the course was } \\
\text { clearly presented. }\end{array}$ & 4.25 & 0.65 \\
\hline \multicolumn{1}{|c|}{ Total } & 4.15 & 0.65 \\
\hline
\end{tabular}




\section{B- Learner Interaction:}

The overall rating of student satisfaction on interaction was moderate to high with total mean of 3.83. Items such as on opportunities to introduce oneself and the chances of engaging in active participation rated relatively high, but the rest of the items rated moderate with the least pertaining to exchange of peer comments. In general, social interaction scored moderate to high.

Table 2: Learner Interaction Results

\begin{tabular}{|c|c|c|c|}
\hline \multicolumn{2}{|c|}{ B- Learner Interaction } & \multirow{2}{*}{$\frac{\text { Mean }}{3.97}$} & \multirow{2}{*}{$\begin{array}{c}\mathrm{SD} \\
0.81\end{array}$} \\
\hline 6 & $\begin{array}{l}\text { I frequently interacted with other } \\
\text { students in the course. }\end{array}$ & & \\
\hline 7 & $\begin{array}{l}\text { There were opportunities for active } \\
\text { learning in this course. }\end{array}$ & 3.94 & 0.57 \\
\hline 8 & $\begin{array}{l}\text { The learning activities promoted } \\
\text { interaction with others. }\end{array}$ & 3.88 & 0.95 \\
\hline 9 & $\begin{array}{l}\text { I had the opportunity to introduce } \\
\text { myself to others in the class. }\end{array}$ & 4.72 & 0.79 \\
\hline 10 & $\begin{array}{l}\text { I communicated often with other } \\
\text { students within the course. }\end{array}$ & 3.89 & 1.01 \\
\hline 11 & $\begin{array}{l}\text { I regularly communicated with the } \\
\text { instructor of the course. }\end{array}$ & 3.07 & 0.92 \\
\hline 12 & $\begin{array}{l}\text { I received ongoing feedback from } \\
\text { my classmates. }\end{array}$ & 3.00 & 0.81 \\
\hline \multicolumn{2}{|r|}{ My Classmates. } & 3.84 & 0.84 \\
\hline
\end{tabular}

\section{C- Student Engagement}

The whole factor as a total scored moderate with a mean of 3.1125 and standard deviation .90. The mean in the below table indicates that the least scoring item was the learner-instructor interaction with a low mean of 2.88, and the highest was in the learner-content interaction with a high mean of 4.19 , implying dedication and commitment from the students' side, but lack of engagement from the faculty members' side.

Table 3: Student Engagement Results

\begin{tabular}{|l|l|c|c|}
\hline \multicolumn{2}{|l|}{ C-Student Engagement } & Mean & SD \\
\hline 13 & $\begin{array}{l}\text { I frequently interacted with my } \\
\text { instructor of this course. }\end{array}$ & 2.88 & 0.80 \\
\hline 14 & $\begin{array}{l}\text { I discussed what I learned in the } \\
\text { course outside of class. }\end{array}$ & 3.63 & 0.88 \\
\hline 15 & $\begin{array}{l}\text { I completed my readings as } \\
\text { assigned during the course. }\end{array}$ & 3.69 & 0.94 \\
\hline 16 & $\begin{array}{l}\text { I participated in synchronous } \\
\text { and/or asynchronous chat } \\
\text { sessions during the course. }\end{array}$ & 3.32 & 0.79 \\
\hline 17 & $\begin{array}{l}\text { I was actively engaged in the } \\
\text { activities required in the course. }\end{array}$ & 4.19 & 0.75 \\
\hline Total & \multicolumn{2}{l}{3.55} & 0.89 \\
\hline
\end{tabular}




\section{D- Instructor Presence}

Student rating on instructor presence in total was 3.2 indicating moderate satisfaction levels. The five items measuring this factor rated between low (mean 2.0) to moderate and moderate-high (3.7). Satisfaction on items pertaining to instructor feedback from assignments was the highest, however, the quality of the comment was low. The feeling of being properly followed up on by the instructor also rated moderate in satisfaction.

Table 4: Instructor Presence Results

\begin{tabular}{|l|l|c|c|}
\hline \multicolumn{2}{|l|}{ D- Instructor Presence } & Mean & SD \\
\hline 18 & $\begin{array}{l}\text { The instructor's feedback on } \\
\text { assignments was clearly stated. }\end{array}$ & 3.82 & 0.40 \\
\hline 19 & $\begin{array}{l}\text { The instructor's feedback on } \\
\text { assignments was constructive. }\end{array}$ & 2.07 & 0.57 \\
\hline 20 & $\begin{array}{l}\text { The instructor provided timely } \\
\text { feedback about my progress in the } \\
\text { course. }\end{array}$ & 3.25 & 0.85 \\
\hline 21 & $\begin{array}{l}\text { The instructor cared about my } \\
\text { progress in this course }\end{array}$ & 3.19 & 0.83 \\
\hline 22 & $\begin{array}{l}\text { I learned from the feedback that } \\
\text { was provided during the course. }\end{array}$ & 3.69 & 0.60 \\
\hline Total & \multicolumn{2}{|l}{3.2} & 0.65 \\
\hline
\end{tabular}

\section{E- Satisfaction}

The overall satisfaction of the e-learner who took the survey was high with a mean of around 4.00. They appeared to be highly satisfied with the learning content and would recommend it to their peers. Less satisfaction was in the instructor himself/herself and student-student interaction.

Table 5: Student Satisfaction Results

\begin{tabular}{|c|c|c|c|}
\hline \multicolumn{2}{|c|}{ E- Student Satisfaction } & Mean & SD \\
\hline 23 & $\begin{array}{l}\text { I am satisfied with my overall } \\
\text { experience in this course. }\end{array}$ & 3.98 & 0.71 \\
\hline 24 & $\begin{array}{l}\text { I would recommend this course to } \\
\text { other students. }\end{array}$ & 4.57 & 0.81 \\
\hline 25 & $\begin{array}{l}\text { I am satisfied with the level of } \\
\text { student interaction that occurred in } \\
\text { the course. }\end{array}$ & 3.97 & 1.09 \\
\hline 26 & $\begin{array}{l}\text { I am satisfied with my learning in } \\
\text { the course. }\end{array}$ & 4.00 & 0.73 \\
\hline 27 & $\begin{array}{l}\text { I am satisfied with the instructor of } \\
\text { the course. }\end{array}$ & 3.97 & 0.51 \\
\hline 28 & $\begin{array}{l}\text { I am satisfied with the content of } \\
\text { the course. }\end{array}$ & 4.00 & 0.36 \\
\hline \multicolumn{2}{|c|}{ Total } & 4.05 & 0.65 \\
\hline
\end{tabular}




\section{F- Perceived Learning}

The total mean of items on students' perceived learning was 4.00. High scoring appeared in satisfaction with learning, learning tasks and understanding of content, acquisition of skills for their future and career. Learning, however, was not much better than what was anticipated.

Table 6: Perceived Learning Results

\begin{tabular}{|l|l|c|c|}
\hline F- Perceived Learning & Mean & SD \\
\hline 29 & $\begin{array}{l}\text { I am pleased with what I learned in } \\
\text { the course. }\end{array}$ & 4.17 & 0.44 \\
\hline 30 & $\begin{array}{l}\text { The learning tasks enhanced my } \\
\text { understanding of the content. }\end{array}$ & 3.94 & 0.44 \\
\hline 31 & $\begin{array}{l}\text { I learned more in the course than I } \\
\text { anticipated. }\end{array}$ & 3.99 & 1.19 \\
\hline 32 & $\begin{array}{l}\text { I learned skills that will help me in } \\
\text { the future. }\end{array}$ & 4.07 & 0.57 \\
\hline 33 & $\begin{array}{l}\text { The learning activities promoted } \\
\text { the achievement of student } \\
\text { learning outcomes. }\end{array}$ & 3.75 & 0.57 \\
\hline 34 & $\begin{array}{l}\text { The course contributed to my } \\
\text { professional development. }\end{array}$ & 4.125 & 0.88 \\
\hline Total & \multicolumn{2}{|l}{4.01} & 0.68 \\
\hline
\end{tabular}

\section{Discussion of Findings}

Findings revealed that five main factors emerged as important to the implementation of the online learning programme in Lebanon, namely: Rationale and Motivating Factors, Technology Infrastructure, E-Learning Pedagogy and Support Infrastructure, Course Design and Delivery and Lessons Learned. The rationale behind offering the online diploma programme was significant in better understanding the current context of universities in Lebanon. It brought forth serious attempts to consider online education as a strategic objective and current experimentation to reach ultimate successful modes of implementation. In their widely spread work, "Barriers to Adoption of On-Line Learning Systems in US Higher Education," Bacow et al. (2012) highlighted four main rationales among American universities to offer online courses and programmes. The leading American universities in Lebanon are in line with two of the aforementioned rationales, namely "the desire to generate new revenue streams by reaching students who wouldn't otherwise enroll in traditional programs" (p. 9) such as international students, and "responding to space constraints" (p. 12) through avoiding expanding or creating expensive additional facilities. On the other hand, improving learning outcomes and increasing retention didn't surface in the conducted interviews as Lebanon is still far from considering online education as a viable option that can generate better learning outcomes and hence become a strategic objective. The presence of online education in the leading university's Master Plan provides clear support at the level of leadership and belief in the value of online learning. The diploma programme places a major focus on the social presence of faculty members, reinforced through high levels of studentfaculty interaction, which is another attestation of the close follow up of the 
managing team on the progress and satisfaction of students as it is highly correlated to learning and retention rates (Drouin et al., 2015; Govindesamay, 2012), and a fundamental pillar of online education best practices (2015). The team's fear of isolated and unhappy learners, hence, calling for more social interaction, concurs with leading universities' attempts, such as SUNY (Pickett et al., 1999). Analysis revealed high technology infrastructure and technical capacities among addressed institutions where the managing team was able to overcome all anticipated problems prior to launching the programme, revealing the operational feasibility of implementation. Among the major contributing factors is the resourcefulness of the leading university, equipped with all the needful resources, from qualified faculty, strong technology capacity that was able to link the processes of admission, registration and course offering among the three universities, to open educational resources with a helpful digital library and experienced instructional designers.

The programme was not only able to overcome perpetuated challenges, but also documented barriers in Lebanon pertaining to inconsistent Internet access and poor network (El Turk \& Cherney, 2016), doubts in the feasibility of implementation (Nasser \& Abouchedid, 2005), resistance among faculty members to teach online (Tarhini et al., 2013), general doubt in perceived usefulness (Nasser and Abouchedid, 2005), and so on. Four main factors contributed to high student learning and satisfaction, namely: Course Structure and Organisation, Learner Interaction, Student Engagement and Instructor Presence. These results are in line with SUNY findings, where the main factors impacting satisfaction and learning effectiveness could be summarised as: faculty-student interaction, peer interaction, social presence and resolving individual difficulties through proper course structure and strong technical infrastructure. Findings reveal that the Lebanese higher education system is on the right track towards paving the way for more creative, innovative and advanced growth in the field of online education in Lebanon. And as the e-learning team manager said during the interview, "we don't wait for the ministry of education to come to us, we go to them."

\section{Strategical Recommendations on Modes of Implementation}

This research reported on the prospects and barriers in designing and implementing an innovative online learning model in the Middle East that proved to be attractive, not because of the machine-guided online instruction element, rather due to the potential of offering improved learning outcomes while bending the cost curve, poising for the growth in the industry. As leaders are contemplating the future of education, particularly given the rapid increase in adoption of online technologies worldwide, the below presents recommendations for universities aiming at developing online learning programmes in the near future.

(i) The presence of strong technological infrastructure is essential to ensure smooth automated progression between admission, registration and course navigation. 
(ii) The presence of specialised instructional designers in abundance is a must, to extensively train faculty members, design faculty development programmes and provide course design support.

(iii) Ample time of no less than three to four months should be given to prepare, test and pilot online courses before publishing. On average 20 to 30 slides will require 18 hours of extensive work to prepare, three hours for audio recordingand two hours for post-production, i.e. publishing and posting. In addition, expectations should be set from the beginning for faculty members regarding due dates, deliverables and consequences if the commitment isn't fulfilled.

(iv) Faculty members' social presence is very important and is underestimated, otherwise there is a risk of isolation of the learner and low completion rates of courses. Online learning students need to continuously feel the presence of faculty members.

(v) A reliable auditing system helps in controlling quality, where auditors are assigned to each online course and conduct satisfaction and progress surveys twice in a semester, in the middle of the semester and towards the end.

(vi) Carrying out live sessions, whether for the purpose of synchronised learning or meeting the students in chat rooms and getting to know them better, appears to be effective in strengthening the faculty member-learner bond.

(vii) The personal effort required from a faculty member to teach an online course is by far huge compared to face-to-face instruction. Hence, monetary rewards as extrinsic factors will help, however, the faculty member should have intrinsic motivational factors to 'buy-in' to online courses and diminish resistance and reluctance.

(viii) Student readiness may seem high, but not all students are tech savvy, hence, students' development programmes are a must.

\section{Conclusion, Limitations and Future Research}

This study aims to present the first approved postgraduate online diploma as a foundational stage for potential growth of the industry in Lebanon. It explores the main factors leading to effective implementation of online program in the higher education sector in Lebanon, students'satisfaction with online learning, and contributing factors to high satisfaction and perceived learning. It has brought forward findings that are critical in the Lebanese context as it presents a departure from the current pervasive classical modes of delivery, overcoming many obstacles documented in literature. Despite known challenges relevant to poor Internet and power quality, lack of funds to finance such projects and fundamental reluctance to teaching online courses not owned by faculty, the mentioned online programme was able to highlight and capture official and public attention. Moreover, despite public doubt regarding the feasibility of implementation of any online programme, the mentioned online programme showed high levels of satisfaction and perceived learning among e-learners. Thus, it could be argued that implementation of online education at undergraduate or post-graduate level is feasible. The rationale and motivation factors, lessons learned from the initial developmental and implementation phases along with the student satisfaction survey will present as a critical report on what has been 
achieved in online education at reputable universities in Lebanon. Findings revealed that five main factors emerged as important to the implementation of the online learning programme in Lebanon, namely: Rationale and Motivating Factors, Technology Infrastructure, E-Learning Pedagogy and Support Infrastructure, Course Design and Delivery and Lessons Learned. A number of factors appeared to contribute to the high student learning and satisfaction, namely: Course Structure and Organisation, Learner Interaction, Student Engagement and Instructor Presence. Findings allowed for the proposal of strategical recommendations on modes of implementation that would optimise potential success pertinent to pedagogy, technology infrastructure, quality control system and key stakeholders' perceptions and readiness. Hence, this study suggests that future research would further investigate online learning in Lebanon in light of that. Moreover, this study recommends including participation of a larger sample of subjects in the student satisfaction survey, while qualitatively re-examining senior stakeholders' opinions post Covid-19.

\section{References}

Abouchedid, K., \& Eid, G. M. (2004). E-learning challenges in the Arab world: revelations from a case study profile. Quality Assurance in Education, 12(1), 15 27. https:// doi.org/10.1108/09684880410517405

Albrahim, F. A. (2020). Online Teaching Skills and Competencies. TOJET: The Turkish Online Journal of Educational Technology, 19(1), 9-20.

Basilaia, G., \& Kvavadze, D. (2020). Transition to Online Education in Schools during a SARS-CoV-2 Coronavirus (COVID-19) Pandemic in Georgia. Pedagogical Research, 5(4). doi:https:// doi.org/10.29333/pr/7937

Fauzi, I., \& Khusuma, I. H. (2020). Teachers' Elementary School in Online Learning of COVID-19 Pandemic Conditions. Jurnal Iqra' : Kajian Ilmu Pendidikan, 5(1), 58-70. https://doi.org/10.25217/ji.v5i1.914

Aparicio, M., Bacao, F., \& Oliveira, T. (2016). An e-Learning Theoretical Framework. Journal of Educational Technology \& Society, 19(1), 292-307. https://www.jstor.org/stable/jeductechsoci.19.1.292

Bacow, L. S., Bowen, W. G., Guthrie, K., M., Lack, K. A., \& Long, M. P. (2012). Barriers to Adoption of Online Learning Systems in U.S. Higher Education. New York: Ithaka.

Basilaia, G., \& Kvavadze, D. (2020). Transition to Online Education in Schools during a SARS-CoV-2 Coronavirus (COVID-19) Pandemic in Georgia. Pedagogical Research, 5(4). https://doi.org/10.29333/pr/7937

Baytiyeh, H. (2017). The flipped classroom model: when technology enhances professional skills. The International Journal of Information and Learning Technology, 34 (1), 51-62. https:/ / doi.org/10.1108/IJILT-07-2016-0025

Brookfield, S. (1995). Adult learning: An overview. International encyclopedia of education, $10,375-380$.

Burns, M. (2017). Online Education Business as a Tool to Boost Economy. Business Community. https://www.business2community.com/tech-gadgets/onlineeducation-business-tool-boost-economy-01972787

Carey, T., \& Trick, D. (2013). How online learning affects productivity, cost and quality in higher education: An environmental scan and review of the literature. Higher Education Quality Council of Ontario.

Carwile, J. (2007). A constructivist a roach to online teaching and learning. Inquiry, 12(1), 68-73. https:/ / eric.ed.gov/ ?id=EJ833907 
Charmaz, K. (2006). Constructing grounded theory: A practical guide through qualitative analysis. Sage.

Chen, L. L. (1997). Distance delivery systems in terms of pedagogical considerations: A $\begin{array}{llll}\text { reevaluation. } & \text { Educational }\end{array}$ https://www.jstor.org/stable/44428405

Center for Education Innovations. (2016). https://www.educationinnovations.org/p/center-for-education-innovationscei

Chickering, A. W., \& Ehrmann, S. C. (1996). Implementing the seven principles: Technology as lever. AAHE bulletin, 49, 3-6

Chickering, A. W., \& Gamson, Z. F. (1991). Appendix A: Seven principles for good practice in undergraduate education. New directions for teaching and learning, 1991(47), 6369.

Doolittle, P. E., \& Camp, W. G. (1999). Constructivism: The career and technical education perspective. Journal of vocational and technical education, 16(1), 23-46. https://eric.ed.gov/?id=EJ598590

Drouin, M., Stewart, J., \& Gorder, K. V. (2015). Using methodological triangulation to examine the effectiveness of a mentoring program for online instructors. Distance Education, 36(3), 400-418. https://doi.org/10.1080/01587919.2015.1081735

Edarabia. (2016). Innovating Education Technology in the Middle East. https://www.edarabia.com/115413/innovating-education-technology-in-themiddle-east/

El Amine, A. (2017). Culture of law at Arab universities. Contemporary Arab Affairs, 10(3), 392-407. https://doi.org/10.1080/17550912.2017.1350368

El Ghali, H., \& Nauffal, D. 2020. COVID19: Is Lebanon Ready for Online Higher Education. https://www.aub.edu.lb/ifi/news/Pages/20200330-covid19-islebanon-ready-for-online-higher-education.aspx

El Turk, S., \& Cherney, I.D. (2016). Perceived online education barriers of administrators and faculty at a US university in Lebanon. Creighton Journal of Interdisciplinary Leadership, 2(1), 15-31. https:/ / eric.ed.gov/?id=EJ1152181

Field, J. (2005). Social capital and lifelong learning. Policy Press.

Gray, J. A., \& DiLoreto, M. (2016). The effects of student engagement, student satisfaction, and perceived learning in online learning environments. International Journal of Educational Leadership Preparation, 11(1), n1. https://eric.ed.gov/?id=EJ1103654

Huang, H. M. (2002). Toward constructivism for adult learners in online learning environments. British journal of educational technology, 33(1), 27-37. https://doi.org/10.1111/1467-8535.00236

Jonassen, D.H., Campbell, J.P., \& Davidson, M.E. (1994). Learning with media: Restructuring the debate. Educational technology research and development, 42(2), 3139. https://www.jstor.org/stable/30218685

Jasmini. (2017). Online Learning Statistics And Trends. https:// elearningindustry.com/online-learning-statistics-and-trends

Koohang, A., Riley, L., Smith, T., \& Schreurs, J. (2009). E-learning and constructivism: from theory to application. Interdisciplinary Journal of E-learning and Learning Objects, 5, 91-109. https://www.learntechlib.org/p/44824/

Li, C., \& Lalani, F. (2020). The COVID-19 pandemic has changed education forever. World Economic Forum. https://www.weforum.org/agenda/2020/04/coronaviruseducation-global-covid19-online-digital-learning/ 
Meyer, K. A. (2012). The influence of online teaching on faculty productivity. Innovative Higher Education, 37(1), 37-52. https:/ /link.springer.com/article/10.1007/s10755011-9183-y

Malaeb, A. (2020). Amid coronavirus, students forced online, but Lebanon won't recognize online degrees. https://english.alarabiya.net/features/2020/12/11/Lebanoncrisis-Amid-coronavirus-students-forced-online-but-Lebanon-won-t-recognizeonline-degrees

Nasser, R., \& Abouchedid, K. (2005). Graduates' perception of university training in light of occupational attainment and university type: The case of Lebanon. Education+ Training.

Pickett, A., \& Shea, P. (1999). The evolution of faculty development and course design at the SUNY Learning Network. In WebNet World Conference on the WWW and Internet (pp. 1393-1394). Association for the Advancement of Computing in Education (AACE). https://www.learntechlib.org/p/7721/

Research and Markets. (2017). Middle East Online Education and E Learning Market Size, Demand, Opportunity E Growth Outlook 2023. https://www.researchandmarkets.com/reports/4326517/middle-east-onlineeducation-and-e-learning

Schell, G.P., \& Janicki, T.J. (2012). Online course pedagogy and the constructivist learning model. Journal of the Southern Association for Information Systems, 1(1), 26-36. http://dx.doi.org/10.3998/jsais.11880084.0001.104

Shaya, N. M. (2018). Adoption and Implementation of Online Learning Systems in Lebanon: Prospects and Barriers (Doctoral dissertation, The British University in Dubai (BUiD)). https://bspace.buid.ac.ae/handle/1234/1291

Shutimarrungson, W., Pumipuntu, S., \& Noirid, S. (2014). A model of e-learning by constructivism approach using problem-based learning to develop thinking skills for students in Rajabhat University. Educational Research and Reviews, 9(21), 11651172. https:// doi.org/10.5897/ERR2014.1800

Spitzer, D.R. (1998). Rediscovering the social context of distance learning. Educational Technology, 38(2), 52-56. https://www.jstor.org/stable/44428438

Suliman, A. M. (2001). Work performance: is it one thing or many things? The multidimensionality of performance in a Middle Eastern context. International Journal of Human Resource Management, 12(6), 1049-1061. https://www.tandfonline.com/doi/abs/10.1080/713769689

Tarhini, A., Hone, K., \& Liu, X. (2013). User acceptance towards web-based learning systems: Investigating the role of social, organizational and individual factors in European higher education. Procedia Computer Science, 17, 189-197. https:// doi.org/10.1016/j.procs.2013.05.026

The Open University. (2021). Annual Report. http://www2.open.ac.uk/about/annualreport-2018-19/

Wagner, E.D., \& McCombs, B.L. (1995). Learner centered psychological principles in practice: Designs for distance education. Educational technology, 35(2), 32-35. https://www.jstor.org/stable/44428961

Yuksel, U. (2010). Integrating curriculum: Developing student autonomy in learning in higher education. Journal of College Teaching $\mathcal{E}$ Learning (TLC), 7(8). https://doi.org/10.19030/tlc.v7i8.138 